\title{
RISK FACTORS FOR DECLINE OF RESIDUAL RENAL FUNCTION IN CHILDREN TREATED WITH PERITONEAL DIALYSIS
}

\author{
Maria Roszkowska-Blaim and Piotr Skrzypczyk \\ Department of Pediatrics and Nephrology, Medical University of Warsaw, Warsaw, Poland
}

\begin{abstract}
- Background: The aim of the study was to assess risk factors for residual renal function (RRF) decline in children during the first/ second year of chronic peritoneal dialysis (PD).

- Methods: The study group included 56 children with end-stage renal disease (ESRD) (age $10.13 \pm 4.86$ years), including 18 on continuous ambulatory PD (CAPD) and 38 on automated PD (APD), in whom we evaluated RRF (daily diuresis $\left[\mathrm{mL} / \mathrm{m}^{2} / 24 \mathrm{~h}\right.$ ], residual glomerular filtration rate (rGFR) $\left[\mathrm{mL} / \mathrm{min} / 1.73 \mathrm{~m}^{2}\right]$ ), etiology of ESRD, PD fluid volume $\left(\mathrm{mL} / \mathrm{m}^{2} / 24 \mathrm{~h}\right)$, glucose load $\left(\mathrm{g} / \mathrm{m}^{2} / 24 \mathrm{~h}\right)$, ultrafiltration $\left(\mathrm{mL} / \mathrm{m}^{2} / 24 \mathrm{~h}\right)$, peritoneal permeability $\left(D / P_{\text {Crea }} 4 \mathrm{~h}^{\prime}\right.$ $\left.D / D_{0 \text { Glu } 4 \mathrm{~h}}\right)$, dialysis adequacy (twKt/V, twCCr $\left.\left[L / w e e k / 1.73 \mathrm{~m}^{2}\right]\right)$, blood pressure (BP), biochemical parameters, and medications used. Duration of follow-up was 24 months.
\end{abstract}

- Results: Mean diuresis before initiation of PD was 1,394.93 \pm $698.37\left(\mathrm{~mL} / \mathrm{m}^{2} / 24 \mathrm{~h}\right)$, and mean rGFR was $7.41 \pm 3.96(\mathrm{~mL} /$ $\left.\min / 1.73 \mathrm{~m}^{2}\right)$. The rate of daily diuresis decline was $-529.34 \pm$ 546.28 in the first year and $-107.10 \pm 291.54\left(\mathrm{~mL} / \mathrm{m}^{2} / 24 \mathrm{~h}\right)$ in the second year $(p=0.005)$, and the rate of rGFR decline was $-3.35 \pm$ 3.73 in the first year and $-1.63 \pm 1.85\left(\mathrm{~mL} / \mathrm{min} / 1.73 \mathrm{~m}^{2}\right)$ in the second year $(p=0.118)$. Eleven $(19.64 \%)$ patients became anuric. In univariate analysis, the rate of daily diuresis decline in the first year was related to baseline diuresis $(r=-0.29, p=0.031)$, proteinuria $(r=-0.43, p=0.001)$, and systolic BP $(r=-0.31, p=$ $0.020) ; 12$-month changes $(\Delta 0-12)$ in PD fluid volume $(r=-0.37$, $p=0.004)$, glucose load $(r=-0.28, p=0.035)$, and ultrafiltration $(r=-0.38, p=0.004)$; serum calcium-phosphorus product $(r=$ $-0.41, p=0.002)$; and $\Delta 0-12$ body mass index (BMI) Z-score $(r=0.30, p=0.024)$; while the rate of rGFR decline in the first year was related only to baseline $\operatorname{rGFR}(r=-0.57, p<0.001)$. In multivariate analysis, significant predictors of the rate of daily diuresis decline in the first year were baseline diuresis $(\beta=-0.386, p<0.001)$ and proteinuria $(\beta=-0.278, p=0.017)$, mean systolic BP Z-score $(\beta=-0.237, p=0.027)$, and age at the onset of PD $(\beta=-0.224, p=0.037)$, while predictors of the rate of rGFR decline were baseline rGFR $(\beta=-0.607, p<0.001)$ and baseline proteinuria $(\beta=-0.225, p=0.046)$. In the second year, the only predictors of the rate of rGFR decline were $D / D_{0}$ Glu $4 \mathrm{~h}$ ( $r=0.44, p=0.033$, univariate analysis) and rGFR at 12 months $(\beta=-0.499, p=0.044)$.

- Conclusion: The most important risk factors for rapid RRF decline in children during the first year of chronic PD include higher baseline daily diuresis and proteinuria, and additional factors are

Correspondence to: Piotr Skrzypczyk, Department of Pediatrics and Nephrology, Medical University of Warsaw, 63a Zwirki i Wigury St, 02-091 Warsaw, Poland.

pskrzyp@gmail.com

Received 4 May 2013; accepted 30 March 2016.

Supplemental material available at www.pdiconnect.com systolic BP and age at the onset of PD; while high baseline GFR and low peritoneal transport status may be the only important factors during the second year.

Perit Dial Int 2016; 36(6):669-675 epub ahead of print: 07 Sept 2016 https://doi.org/10.3747/pdi.2014.00123

KEY WORDS: Residual renal function; children; peritoneal dialysis.

Dreservation of residual renal function (RRF) for as long $P$ as possible is still considered one of the most important prognostic factors in adults with end-stage renal disease (ESRD) treated with chronic peritoneal dialysis (PD) (1). Numerous benefits from preservation of diuresis have also been shown in pediatric patients. Children with preserved RRF treated with PD are characterized by a faster growth rate, better nutritional status, reduced burden to the cardiovascular system, higher hemoglobin level, less severe disturbances of the calcium-phosphorus metabolism, and a lower risk of dialysis-related peritonitis (2). Recent data suggest that the rate of RRF decline is a more powerful prognostic factor than the baseline RRF, associated with mortality and technical failures in adult patients on long-term PD (3), and proteinuria together with baseline glomerular filtration rate (GFR) are independently related to the rate of RRF decline in adult continuous ambulatory PD (CAPD) patients (4). The aim of the study was to assess factors affecting the rate of RRF decline in children during the first and second year of chronic PD treatment.

\section{MATERIAL AND METHODS}

We retrospectively studied children with ESRD treated with chronic PD. The inclusion criteria were preserved RRF and PD being the initial method of renal replacement therapy (RRT) used for at least 12 months. Exclusion criteria included treatment with hemodialysis during acute and/or end-stage renal failure, renal agenesis, and previous unilateral nephrectomy.

Dialysis fluid exchanges were performed manually (CAPD) or automatically (automated PD [APD]) by Baxter Homechoice cyclers (Baxter International Inc., Deerfield, Illinois, USA), using $30-50 \mathrm{~mL} / \mathrm{kg}$ of PD fluid containing $1.36 \%, 2.27 \%$, or $3.86 \%$ glucose, or a glucose polymer icodextrin-containing solution (Extraneal; Baxter International Inc., Deerfield,

This single copy is for your personal, non-commercial use only.

For permission to reprint multiple copies or to order presentation-ready

copies for distribution, contact Multimed Inc. at marketing@multi-med.com 
Illinois, USA). Dialysis therapy was individualized to provide its adequacy.

Residual renal function was evaluated based on daily diuresis $\left(\mathrm{mL} / \mathrm{m}^{2} / 24 \mathrm{~h}\right)$ prior to initiation of RRT and every 3 months thereafter, and residual glomerular filtration rate (rGFR) $\left(\mathrm{mL} / \mathrm{min} / 1.73 \mathrm{~m}^{2}\right)$ was calculated every 6 months for 24 months using averaged urea and creatinine clearance in a 24-hour urine collection (5). Anuria was defined as daily urine output $<50\left(\mathrm{~mL} / \mathrm{m}^{2} / 24 \mathrm{~h}\right)(6)$. Body surface area was calculated using Gehan and George equation (5).

Among potential factors that might affect the rate of RRF loss during 24 months of chronic PD, we evaluated the following: gender, age at the initiation of RRT (years), the cause of ESRD categorized according to the pediatric European Renal Association-European Dialysis and Transplant Association (ERA-EDTA) registry (7), duration of chronic kidney disease, baseline RRF parameters including daily diuresis and rGFR, BMI Z-score (8), BP; parameters of dialysis treatment including dialysis modality (APD: nocturnal intermittent PD [NIPD]/continuous cycling PD [CCPD], CAPD), dialysis fluid volume ( $\mathrm{mL} /$ $\left.\mathrm{m}^{2} / 24 \mathrm{~h}\right)$, glucose load $\left(\mathrm{g} / \mathrm{m}^{2} / 24 \mathrm{~h}\right)$, and ultrafiltration $(\mathrm{mL} /$ $\mathrm{m}^{2} / 24 \mathrm{~h}$ ); adequacy parameters including total weekly clearance of urea (twKt/V) and creatinine (twCCr) $\left(\mathrm{L} /\right.$ week/1.73 $\left.\mathrm{m}^{2}\right)$ (5), all at baseline and at 12 and 24 months; peritoneal permeability by the peritoneal equilibration test $(\mathrm{PET})\left(\mathrm{D} / \mathrm{P}_{\mathrm{Crea} 4 \mathrm{~h}}\right.$ and $\left.\mathrm{D} / \mathrm{D}_{0 \text { Glu } 4 \mathrm{~h}}\right)$ performed within 3 months of initiation of chronic $\mathrm{PD}$ and during the first 3 months of the second year of treatment (9); and the rate of dialysis-related peritonitis in relation to aminoglycoside use. Systolic and diastolic BP (SBP and DBP) were measured using the auscultatory method and expressed as Z-scores according to the Fourth Report on the Diagnosis, Evaluation, and Treatment of High Blood Pressure in Children and Adolescents (10). Arterial hypertension was defined as SBP or DBP $\geq 95^{\text {th }}$ percentile or the use of antihypertensive medications, and poorly controlled hypertension as SBP or DBP $\geq 90^{\text {th }}$ percentile despite use of antihypertensive drugs (10). Among factors that might affect the rate of RRF loss, we also considered laboratory parameters including serum hemoglobin $(\mathrm{g} / \mathrm{dL})$, total protein $(\mathrm{g} / \mathrm{dL})$, albumin $(\mathrm{g} / \mathrm{dL})$, cholesterol $(\mathrm{mg} /$ $\mathrm{dL})$, triglycerides $(\mathrm{mg} / \mathrm{dL})$, calcium-phosphorus (Ca $\times \mathrm{P})$ product $\left(\mathrm{mg}^{2} / \mathrm{dL}^{2}\right.$ ) (with normal values defined as $<55 \mathrm{mg}^{2} / \mathrm{dL}^{2}$ in adolescents $>12$ years and $<65 \mathrm{mg}^{2} / \mathrm{dL}^{2}$ in younger children [11]), serum parathormone $(\mathrm{PTH})(\mathrm{pg} / \mathrm{mL})$ (reference range $200-300 \mathrm{pg} / \mathrm{mL}$ [11]), and baseline proteinuria (mg/kg/ $24 \mathrm{~h}$ ); and use of erythropoiesis-stimulating agents (ESA) (IU/kg/week), calcium carbonate $(\mathrm{g} / \mathrm{kg} / 24 \mathrm{~h})$, alfacalcidol $(\mu \mathrm{g} / \mathrm{kg} / 24 \mathrm{~h})$, and recombinant human growth hormone (rhGH). Total duration of follow-up was 24 months.

Statistical analyses were performed using the Statistica software platform version 9.0 PL (StatSoft, Inc., Tulsa, Oklahoma, USA). Dialysis parameters were evaluated as differences between baseline and 12 months or 12 and 24 months, and BP and biochemical parameters as mean annual values. For the purpose of statistical analysis, we considered drugs taken for at least 6 months during the study period. Normal distribution of the data was evaluated by the Shapiro-Wilk test.
Values were expressed as mean values \pm standard deviation (SD) or median values and interquartile range (IQR), when appropriate. Differences between groups were evaluated using the Student $t$ test, Mann-Whitney U test, ANOVA, or KruskalWallis test when appropriate. Differences between values of the same parameters at different time points were compared using the Student $t$ test for paired samples or the Wilcoxon test depending on variable distribution. Correlations between the rate of RRF loss and continuous variables were evaluated using Pearson and Spearman correlation coefficients where applicable. Variables related to the rate of daily diuresis or rGFR decline with $p<0.200$ were analyzed by multivariate analysis performed using analysis of covariance (ANCOVA) and step-wise regression. Qualitative variables such as dialysis modality (CAPD/APD), use of angiotensin-converting enzyme inhibitors, etc. were evaluated using ANCOVA. Statistical significance level was defined as $p<0.05$.

\section{RESULTS}

In our study group of 56 children ( 40 boys, 16 girls, mean age $10.13 \pm 4.86$ years), 18 children were treated with CAPD and 38 were treated with APD (19 with nocturnal intermittent PD [NIPD] and 19 with continuous cycling PD [CCPD]). The mean duration of PD treatment was $27.52 \pm 23.50$ months (range 12 - 75 months). All 56 children were followed-up for 12 months and 26 (46.4\%) were followed-up for 24 months. Reasons for terminating follow-up after the first year included anuria during the first year in $6(10.8 \%)$ children and termination of CAPD or APD treatment during the second year due to kidney transplantation in 19 children $(33.9 \%)$, and transfer to a hemodialysis treatment program in 5 children (8.9\%).

Clinical data of the 56 studied children are shown in Table 1. The most common causes of ESRD in the study group were congenital anomalies of kidneys and urinary tracts (CAKUT), cystic kidney disease, and hereditary nephropathy. Mean daily diuresis before initiation of PD was 1,394.93 \pm $698.37 \mathrm{~mL} / \mathrm{m}^{2} / 24 \mathrm{~h}$ (range: $267.81-3,302.76$ ) and was highest in children with CAKUT $\left(1,946.39 \pm 607.78 \mathrm{~mL} / \mathrm{m}^{2} / 24 \mathrm{~h}\right)$, significantly higher compared with mean values in children with glomerulonephritis $\left(990.58 \pm 624.12 \mathrm{~mL} / \mathrm{m}^{2} / 24 \mathrm{~h}, p=\right.$ $0.018)$, cystic kidney disease $\left(1,117.71 \pm 340.75 \mathrm{~mL} / \mathrm{m}^{2} / 24 \mathrm{~h}\right.$, $p=0.005)$, hereditary nephropathy $(1,017.83 \pm 541.90 \mathrm{~mL} /$ $\left.\mathrm{m}^{2} / 24 \mathrm{~h}, p=0.013\right)$, and miscellaneous causes $(1,029.16 \pm$ $\left.660.14 \mathrm{~mL} / \mathrm{m}^{2} / 24 \mathrm{~h}, p=0.027\right)$. The median value of $\mathrm{rGFR}$ was $7.51 \mathrm{~mL} / \mathrm{min} / 1.73 \mathrm{~m}^{2}$ (IQR: 4.53 - 9.96), with no significant differences between children with different etiologies of ESRD $(p=0.353)$. Before initiation of RRT, hypertension was found in 35 children $(62.5 \%)$, including poorly controlled hypertension in $25(71.4 \%)$ children; and proteinuria in 43 children $(76.8 \%)$, including nephrotic range proteinuria in 21 (37.5\%) children. Serum PTH level was within the reference range for children with ESRD in 9 children (16.1\%), below $200 \mathrm{pg} / \mathrm{mL}$ in 34 children $(60.7 \%)$, and above $300 \mathrm{pg} / \mathrm{mL}$ in 13 children $(23.2 \%)$; and $\mathrm{Ca} \times \mathrm{P}$ product was within the recommended range in 38 patients $(67.9 \%)$ (11). 
TABLE 1

Clinical Characteristics of Children with End-Stage Renal Disease Treated with Chronic Peritoneal Dialysis

\begin{tabular}{|c|c|}
\hline Females/Males (\%) & $16 / 40(28.6 \% / 71.4 \%)$ \\
\hline Age (years) & $10.13 \pm 4.86$ \\
\hline Age at the diagnosis of CKD (years) & $5.96(1.42-10.38)$ \\
\hline Duration of CKD (years) & $2.50(0.25-5.63)$ \\
\hline \multicolumn{2}{|l|}{ Causes of ESRD: $(n, \%)$} \\
\hline I. Glomerulonephritis & $6(10.7 \%)$ \\
\hline II. CAKUT & $20(35.7 \%)$ \\
\hline III. Cystic kidney disease & $12(21.4 \%)$ \\
\hline IV. HUS & $2(3.6 \%)$ \\
\hline V. Hereditary & $8(14.3 \%)$ \\
\hline VI. Miscellaneous & $6(10.7 \%)$ \\
\hline VII. Unknown & $2(3.6 \%)$ \\
\hline Baseline diuresis $\left(\mathrm{mL} / \mathrm{m}^{2} / 24 \mathrm{~h}\right)$ & $1,394.93 \pm 698.37$ \\
\hline Baseline rGFR (mL/min/1.73 $\left.\mathrm{m}^{2}\right)$ & $6.51(4.53-9.96)$ \\
\hline BMI Z-score & $-0.64 \pm 1.17$ \\
\hline SBP Z-score & $1.55 \pm 1.69$ \\
\hline DBP Z-score & $1.31 \pm 1.28$ \\
\hline Presence of arterial hypertension $(n, \%)$ & $35(62.5 \%)$ \\
\hline Poorly controlled hypertension $(n, \%)$ & $25(71.4 \%)$ \\
\hline Number of antihypertensive medications $(n)$ & $2(1-3)$ \\
\hline Hemoglobin $(\mathrm{g} / \mathrm{dL})$ & $9.89 \pm 1.76$ \\
\hline Total protein $(\mathrm{g} / \mathrm{dL})$ & $6.39 \pm 1.04$ \\
\hline Albumin $(\mathrm{g} / \mathrm{dL})$ & $3.55 \pm 0.71$ \\
\hline \multirow{2}{*}{ Proteinuria $(n)(\mathrm{mg} / \mathrm{kg} / 24 \mathrm{~h})$} & $43(76.8 \%)$ \\
\hline & $49.00(5.88-81.70)$ \\
\hline Cholesterol (mg/dL) & $235.89 \pm 70.96$ \\
\hline Triglycerides (mg/dL) & $198(142-275)$ \\
\hline $\mathrm{Ca} \times \mathrm{P}\left(\mathrm{mg}^{2} / \mathrm{dL}^{2}\right)$ & $53.65 \pm 14.19$ \\
\hline PTH (pg/mL) & $143(50-294)$ \\
\hline \multirow{2}{*}{$\mathrm{ESA}(n)(\mathrm{IU} / \mathrm{kg} /$ week $)$} & $39(69.6 \%)$ \\
\hline & $68.09(44.44-105.26)$ \\
\hline \multirow{2}{*}{ CaC03 $(n)(\mathrm{g} / \mathrm{kg} /$ week) } & $53(94.6 \%)$ \\
\hline & $0.14(0.07-0.23)$ \\
\hline \multirow[t]{3}{*}{ Alfacalcidol $(n)(\mu \mathrm{g} / \mathrm{kg} /$ week $)$} & $48(85.7 \%)$ \\
\hline & $0.07(0.03-0.11)$ \\
\hline & $6(10.7 \%)$ \\
\hline
\end{tabular}

$\mathrm{CKD}=$ chronic kidney disease; $\mathrm{ESRD}=$ end-stage renal disease; $\mathrm{CAKUT}=$ congenital anomalies of kidney and urinary tract; HUS = hemolyticuremic syndrome; $r G F R=$ residual glomerular filtration rate; $B M I=$ body mass index; $\mathrm{SBP}=$ systolic blood pressure; $\mathrm{DBP}=$ diastolic blood pressure; $\mathrm{Ca} \times \mathrm{P}=$ calcium phosphate product; $\mathrm{PTH}=$ parathormone; $\mathrm{ESA}=$ erythropoiesis-stimulating agent; $\mathrm{CaCO} 3$ = calcium carbonate; rhGH = recombinant human growth hormone.

Dialysis parameters, infectious complications of PD, and RRF during 24 months in the study group are shown in Table 2. Peritoneal transport status by PET in the first and second year of treatment was high-average in 18 (32.14\%) and 10 $(38.5 \%)$ children, respectively; low-average in $18(32.14 \%)$ and 9 (34.6\%) children; high in $12(21.43 \%)$ and 7 (26.9\%) children; and low in only 8 (14.29\%) children in the first year, the differences being non-significant. In the group of 26 children treated with chronic PD for 24 months, no significant differences in $\mathrm{D} / \mathrm{P}_{\text {Crea } 4 \mathrm{~h}}$ and $\mathrm{D} / \mathrm{D}_{0 \text { Glu } 4 \mathrm{~h}}$ were found during the first and second year of treatment.
During the first year of treatment, we found significant increases $(p<0.001)$ in PD fluid volume, glucose load, and ultrafiltration, while changes during the second year were non-significant. Mean twKt/V values were consistent with the KDOQI guidelines, and mean twCCr decreased significantly $(p<0.001)$ during the first year and remained stable during the second year.

Dialysis-related peritonitis occurred in 20 (35.7\%) children, ranging from 1 to 6 (median 1) episodes per patient at the rate of $1 / 31.74$ and $1 / 26$ patient-months, respectively. Aminoglycosides were used in the treatment of dialysis-related peritonitis in 10 children. No difference in the rate of infectious complications of PD was found between the first and the second year of PD treatment.

During the first year of chronic PD treatment, mean daily diuresis and rGFR decreased significantly, while in the second year a significant reduction was seen only for rGFR $(p<0.001)$ (Figure 1). The mean annual rate of daily diuresis decline was significantly higher in the first year compared with the second year $\left(-529.34 \pm 546.2\right.$ vs $-107.10 \pm 291.54\left[\mathrm{~mL} / \mathrm{m}^{2} / 24 \mathrm{~h}\right]$,
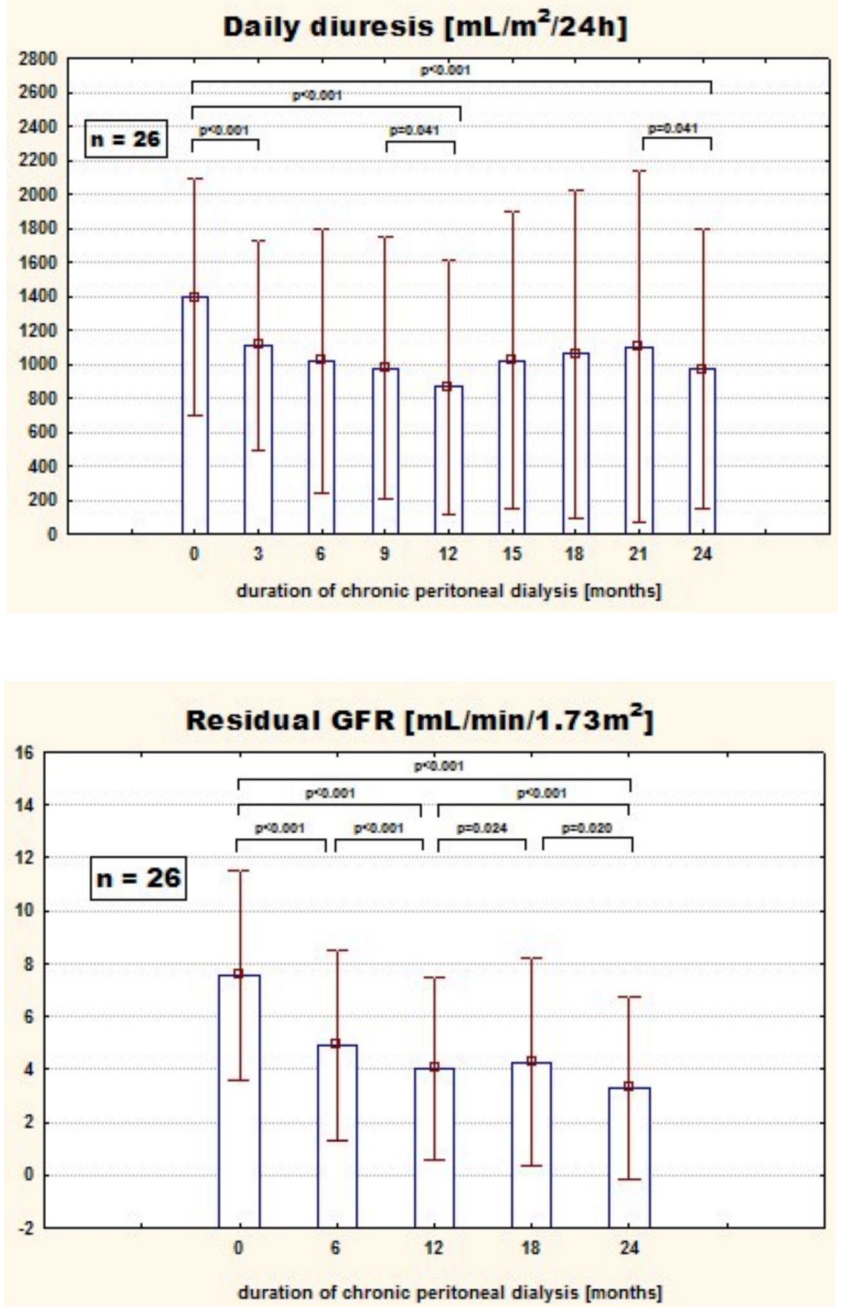

Figure 1 - Daily diuresis $\left[\mathrm{mL} / \mathrm{m}^{2} / 24 \mathrm{~h}\right]$ and $\mathrm{rGFR}\left[\mathrm{mL} / \mathrm{min} / 1.73 \mathrm{~m}^{2}\right]$ during 24 months of treatment with chronic peritonal dialysis (Student $t$ test for paired samples). GFR = glomerular filtration rate.

This single copy is for your personal, non-commercial use only.

For permission to reprint multiple copies or to order presentation-ready 
TABLE 2

Dialysis Parameters and Residual Renal Function in Children Treated with Chronic Peritoneal Dialysis

\begin{tabular}{|c|c|c|c|c|c|c|}
\hline & \multicolumn{3}{|c|}{ Observation period (months) } & \multicolumn{3}{|c|}{ Observation period (months) } \\
\hline & 0 & 12 & $P$ & 12 & 24 & $P$ \\
\hline Number of patients $(n)$ & \multicolumn{2}{|c|}{$n=56$} & \multicolumn{4}{|c|}{$n=26$} \\
\hline $\operatorname{APD} / \mathrm{CAPD}(n, \%)$ & \multicolumn{2}{|c|}{$38 / 18(67.9 \% / 32.1 \%)$} & & \multicolumn{3}{|c|}{$18 / 8(69.2 \% / 30.8 \%)$} \\
\hline APD: NIPD/CCPD $(n, \%)$ & \multicolumn{2}{|c|}{$38: 19 / 19(50.0 \% / 50.0 \%)$} & & \multicolumn{3}{|c|}{$18: 8 / 10(44.4 \% / 56.6 \%)$} \\
\hline $\begin{array}{ll}\text { PET } & D / P_{\text {Crea } 4 h} \\
& D / D^{2}\end{array}$ & \multicolumn{2}{|c|}{$0.65 \pm 0.13$} & $\begin{array}{l}0.233 \\
0.395\end{array}$ & \multicolumn{3}{|c|}{$0.70 \pm 0.12$} \\
\hline $\begin{array}{l}\text { Total dialysate volume } \\
\left(\mathrm{mL} / \mathrm{m}^{2} / 24 \mathrm{~h}\right)\end{array}$ & $\begin{array}{c}6,643.26 \\
(2,516.56-4,785.06)\end{array}$ & $\begin{array}{c}5,052.68 \\
(3,259.60-6,512.68)\end{array}$ & $<0.001$ & $\begin{array}{c}4,972.32 \\
(3,173.00-6,526.68)\end{array}$ & $\begin{array}{c}5,136.53 \\
(3,649.59-7,481.24)\end{array}$ & 0.151 \\
\hline $\begin{array}{l}\text { Glucose load } \\
\left(\mathrm{g} / \mathrm{m}^{2} / 24 \mathrm{~h}\right)\end{array}$ & $\begin{array}{c}52.40 \\
(35.87-65.08)\end{array}$ & $\begin{array}{c}76.72 \\
(47.60-110.35)\end{array}$ & $<0.001$ & $\begin{array}{c}68.72 \\
(46.33-109.60)\end{array}$ & $\begin{array}{c}75.63 \\
(51.07-109.68)\end{array}$ & 0.182 \\
\hline $\begin{array}{l}\text { Ultrafiltration } \\
\left(\mathrm{mL} / \mathrm{m}^{2} / 24 \mathrm{~h}\right)\end{array}$ & $\begin{array}{c}360.44 \\
(195.52-513.95)\end{array}$ & $\begin{array}{c}575.47 \\
(263.62-841.12)\end{array}$ & $<0.001$ & $\begin{array}{c}472.76 \\
(196.90-836.75)\end{array}$ & $\begin{array}{c}468.02 \\
(243.31-894.71)\end{array}$ & 0.534 \\
\hline \multicolumn{7}{|l|}{ Adequacy of peritoneal dialysis } \\
\hline twKt/V & $\begin{array}{c}2.65 \\
(2.27-3.26)\end{array}$ & $\begin{array}{c}2.55 \\
(2.09-2.96)\end{array}$ & 0.130 & $\begin{array}{c}2.56 \\
(2.44-2.87)\end{array}$ & $\begin{array}{c}2.51 \\
(2.18-2.86)\end{array}$ & 0.653 \\
\hline $\begin{array}{l}\mathrm{twCCr} \\
(\mathrm{L} / \text { week/1.73 m²) }\end{array}$ & $\begin{array}{c}100.74 \\
(77.25-129.50)\end{array}$ & $\begin{array}{c}72.53 \\
(48.67-104.80)\end{array}$ & $<0.001$ & $\begin{array}{c}78.20 \\
(64.30-110.00)\end{array}$ & $\begin{array}{c}72.90 \\
(58.00-85.27)\end{array}$ & 0.114 \\
\hline \multicolumn{7}{|c|}{ Peritoneal dialysis-associated complications } \\
\hline Peritonitis rate $(1 / \mathrm{pts})$ & \multicolumn{2}{|c|}{$1 / 31.74$} & 0.739 & \multicolumn{2}{|c|}{$1 / 26$} & \\
\hline Tunnel infections (1/pts) & \multicolumn{2}{|c|}{$1 / 672$} & 0.544 & \multicolumn{3}{|c|}{$1 / 312$} \\
\hline Exit-site infections ( $1 / \mathrm{pts})$ & \multicolumn{2}{|c|}{$1 / 22.56$} & 0.652 & \multicolumn{3}{|c|}{$1 / 26.75$} \\
\hline $\begin{array}{l}\text { Aminoglycoside use } \\
\text { ( } n, \% \text { of peritonitis) }\end{array}$ & \multicolumn{2}{|c|}{$15 / 31(47.83 \%)$} & 0.191 & \multicolumn{2}{|c|}{$3 / 12(25.0 \%)$} & \\
\hline \multicolumn{7}{|l|}{ Residual renal function } \\
\hline $\begin{array}{l}\text { Daily diuresis } \\
\left(\mathrm{mL} / \mathrm{m}^{2} / 24 \mathrm{~h}\right)\end{array}$ & $1,394.93 \pm 698.37$ & $865.59 \pm 752.15$ & $<0.001$ & $1,069.14 \pm 795.13$ & $972.01 \pm 870.50$ & 0.084 \\
\hline $\begin{array}{l}\mathrm{rGFR} \\
\left(\mathrm{mL} / \mathrm{min} / 1.73 \mathrm{~m}^{2}\right)\end{array}$ & $\begin{array}{c}6.51 \\
(4.53-9.96)\end{array}$ & $\begin{array}{c}2.97 \\
(1.05-6.74)\end{array}$ & $<0.001$ & $\begin{array}{c}4.83 \\
(2.68-7.08)\end{array}$ & $\begin{array}{c}2.61 \\
(0.83-4.86)\end{array}$ & $<0.001$ \\
\hline
\end{tabular}

$\mathrm{APD}=$ automated peritoneal dialysis; $\mathrm{CAPD}=$ continuous ambulatory peritoneal dialysis; NIPD = nocturnal intermittent peritoneal dialysis; $C C P D=$ continuous cycling peritoneal dialysis; $\mathrm{PET}=$ peritoneal equilibration test; $\mathrm{twKt} / \mathrm{V}=$ total weekly Kt $/ \mathrm{V}$; $\mathrm{twCCr}=$ total weekly clearance of creatinine; $p t s=$ patient-month; $r G F R=$ residual glomerular filtration rate.

$p=0.005)$. The mean annual rate of rGFR decline was also higher in the first year compared with the second year, but the difference was not significant $(-3.35 \pm 3.73$ vs $-1.63 \pm 1.85$ $\left.\left[\mathrm{mL} / \mathrm{min} / 1.73 \mathrm{~m}^{2}\right], p=0.118\right)$. During 24 months, we found positive correlations in our study group between mean daily diuresis and rGFR (before treatment initiation: $r=0.49, p<$ 0.001 ; after 12 months: $r=0.83, p<0.001$; after 24 months: $r=$ $0.82, p<0.001)$ and between the rate of daily diuresis decline and rGFR (in the first year: $r=0.44, p=0.001$; in the second year: $r=0.52, p=0.009$ ).

During 2 years of chronic PD treatment, 11 patients (19.64\%) became anuric, including 6 patients (10.71\%) during the first year and $5(19.23 \%)$ during the second year. All these patients had proteinuria (mean: $204.4 \pm 163.0 \mathrm{mg} /$ $\mathrm{kg} / 24 \mathrm{~h}$, range $15.4-436.4)$, including nephrotic range proteinuria in 10 patients $(90.9 \%)$, and 10 patients $(90.9 \%)$ had hypertension, including poorly controlled hypertension in $7(63.6 \%)$ patients.
In univariate analysis evaluating the effects of selected parameters on the rate of RRF loss in the study group in the first year of PD treatment, we found negative correlations of the rate of daily diuresis decline $\left(\mathrm{mL} / \mathrm{m}^{2} / 24 \mathrm{~h}\right)$ with baseline diuresis $\left(\mathrm{mL} / \mathrm{m}^{2} / 24 \mathrm{~h}\right)(r=-0.29, p=0.031)$, proteinuria $(\mathrm{mg} / \mathrm{kg} / 24 \mathrm{~h})(r=-0.43, p=0.001)$; mean SBP Z-score $(r=-0.31, p=0.020), 12$-month increases in PD fluid volume $\left(\mathrm{mL} / \mathrm{m}^{2} / 24 \mathrm{~h}\right)(r=-0.37, p=0.004)$, glucose load $\left(\mathrm{g} / \mathrm{m}^{2} / 24 \mathrm{~h}\right)$ $(r=-0.28, p=0.035)$, and ultrafiltration $\left(\mathrm{mL} / \mathrm{m}^{2} / 24 \mathrm{~h}\right)$ $(r=-0.38, p=0.004)$; and $\mathrm{Ca} \times \mathrm{P}$ product $(r=-0.41, p=$ $0.002)$; and a positive correlation with 12-month increase in BMI Z-score $(r=0.30, p=0.024)$. The rate of rGFR decline in the first year correlated significantly only with baseline rGFR $\left(\mathrm{mL} / \mathrm{min} / 1.73 \mathrm{~m}^{2}\right)(r=-0.57, p<0.001)$ (Supplementary Table 1).

In univariate analysis performed for the second year of PD treatment, none of the evaluated parameters was a significant predictor of the rate of daily diuresis decline, while the 
rate of rGFR decline correlated only with $\mathrm{D} / \mathrm{D}_{0 \text { Glu } 4 \mathrm{~h}}(r=0.44$, $p=0.033$ ) (Supplementary Table 2).

In multivariate analysis by ANCOVA, we found no significant effect of hypertension and the use of angiotensin-converting enzyme inhibitors on the rate of daily diuresis decline during the first 12 months of treatment with PD, and thus these variables were removed from further analyses. Analysis by stepwise regression showed negative correlations between the rate of daily diuresis decline during the first year of treatment and baseline diuresis $(\beta=-0.386, p<0.001)$ and proteinuria $(\beta=-0.278, p=0.017)$, mean SBP Z-score $(\beta=-0.237, p=$ $0.027)$, and age at the onset of PD $(\beta=-0.224, p=0.037)$. Similarly, analysis by ANCOVA showed no significant effect of the cause of chronic kidney disease and the use of angiotensinconverting enzyme inhibitors on the rate of rGFR decline during the first 12 months of treatment with PD. Analysis by stepwise regression showed that the rate of $\mathrm{rGFR}$ decline during the first year of treatment was related to baseline rGFR $(\beta=-0.607$, $p<0.001)$ and proteinuria $(\beta=-0.225, p=0.046)$.

During the second year of treatment with PD, no variables were significantly related to the rate of daily diuresis decline by multivariate analysis. Analysis by ANCOVA showed no significant effect of the PD modality (CAPD/APD) on the rate of rGFR decline during the second year of treatment, and thus this variable was excluded from further analyses. Analysis by stepwise regression showed that the rate of rGFR decline during the second year of treatment was significantly related only to rGFR at 12 months of treatment $(\beta=-0.499, p=0.044)$ (Table 3$)$.

\section{DISCUSSION}

The rate of RFF loss in our study group of children treated with chronic PD was related in the first year to baseline diuresis, rGFR, proteinuria, SBP and age at PD onset and, in the second year, only baseline rGFR. Individualization of PD to provide appropriate ultrafiltration and dialysis adequacy may also have an effect on the rate of RRF decline but only during the first year.

Our results indicating a more rapid rate of RRF loss in children with higher baseline diuresis/rGFR are consistent with observations in adult patients treated with PD $(4,12)$. This association may be explained by the results of the study by Shin et al., who showed that after initiation of PD, diuresis decreases exponentially and not linearly (13). With large urine volumes, the rate of diuresis decline is initially very rapid but decreases later, which was also shown in our 24-month follow-up. On the other hand, in patients in whom RRT is initiated at a very low urine volume, anuria develops more rapidly despite a lower absolute rate of diuresis decline (14).

Proteinuria, along with hypertension, is one of the most important factors promoting progression of predialysis chronic kidney disease in both adults and children (15). In our group of patients with ESRD treated with PD, the rate of RRF loss was directly related to the degree of proteinuria. Moreover, proteinuria was present in all children who became anuric in the studied period, with $90.9 \%$ of them having nephrotic range proteinuria. These results, similarly to findings in adult patients $(3,16,17)$, indicate a strong adverse effect of large proteinuria on renal function also after initiation of RRT.

In the first year of PD treatment, we found a negative correlation between the rate of daily diuresis decline and an increase in dialysis fluid volume, glucose load, and ultrafiltration. Similarly, a faster rate of RRF loss was shown in adult patients treated with chronic PD with large dialysis fluid volumes (16), high glucose load (4), and high values of ultrafiltration (18), suggesting that overly aggressive dehydration leads to hypoperfusion and a decline in native kidney function.

In univariate analysis, we found more rapid decline of residual GFR in children with low peritoneal permeability for glucose in the second year of observation. In contrast, no relationship between daily diuresis and the degree of peritoneal permeability in children with ESRD treated with chronic PD was found in the multicenter TUPEPD study (19). In adult patients, the relationships between RRF and the degree of peritoneal permeability are not clear $(20,21)$. Persistence of larger diuresis in patients with more rapid peritoneal transport may be explained by better kidney perfusion related to an increased intravascular volume (20); on the other hand, these patients may be at risk of a more rapid diuresis loss secondary to increased inflammation and kidney damage by proinflammatory cytokines (21).

In our study group, we found no influence of peritonitis and the rate of aminoglycoside on rate of RRF loss in both first and second year of PD, and none of the patients who became anuric in the firstyear had peritonitis. In children treated with CAPD/ APD, Schaefer noted a significant $(p=0.0005)$ irreversible reduction of GFR following episodes of peritonitis regardless of the treatment used. Peritonitis was the cause of anuria in $19 \%$ of children. However, patients who became anuric during episodes of peritonitis had a marginal preperitonitic rGFR $\left(0.71 \pm 0.32 \mathrm{~mL} / \mathrm{min} / 1.73 \mathrm{~m}^{2}\right)(22)$. In adults, both a negative effect of aminoglycosides (23) and no effect of these drugs on RRF (24) has been noted. A negative effect of peritonitis itself has also been suggested, related to kidney damage by inflammatory mediators (24).

We found a significantly higher rate of daily diuresis decline during the first year of follow-up in children with higher mean SBP values, with hypertension present in $90.9 \%$ and poorly controlled hypertension present in $63.6 \%$ of children who became anuric. Cross-sectional studies in pediatric patients showed a negative relationship between daily diuresis and blood pressure (2). In adult patients, the effect of hypertension and antihypertensive medications on preservation of RRF is not clear $(12,21,23,25)$. Inhibition of the renin-angiotensin-aldosterone (RAA) system is one possible mechanism affecting the rate of RRF loss in patients receiving RRT. Small controlled trials showed a positive effect of ramipril (26) and valsartan (27) on the rate of RRF loss in adult patients treated with $\mathrm{PD}$, but an analysis of 416 patients in the NECOSAD study did not show a role of RAA system inhibition in preservation of diuresis (28), which is consistent with our findings in children.

This single copy is for your personal, non-commercial use only. 
TABLE 3

Multivariate Analysis of Variables Influencing the Rate of Residual Renal Function Decline in Children During the First and Second Year of Treatment with Peritoneal Dialysis

\begin{tabular}{|c|c|c|}
\hline Variable & Standardized beta & $P$ \\
\hline \multicolumn{3}{|l|}{ Rate of daily diuresis decline during the first year of CPD } \\
\hline Baseline diuresis $\left(\mathrm{mL} / \mathrm{m}^{2} / 24 \mathrm{~h}\right)$ & -0.386 & $<0.001$ \\
\hline Baseline proteinuria (mg/kg/24 h) & -0.278 & 0.017 \\
\hline Mean systolic blood pressure Z-score & -0.237 & 0.027 \\
\hline Age at the onset of CPD (years) & -0.224 & 0.037 \\
\hline 12 -month increase in ultrafiltration $\left(\mathrm{mL} / \mathrm{m}^{2} / 24 \mathrm{~h}\right)$ & -0.182 & 0.136 \\
\hline 12-month increase in BMI Z-score & 0.127 & 0.284 \\
\hline 12-month increase in PD fluid volume $\left(\mathrm{mL} / \mathrm{m}^{2} / 24 \mathrm{~h}\right)$ & -0.175 & 0.295 \\
\hline Baseline BMI Z-score & -0.067 & 0.537 \\
\hline 12-month increase in glucose load $\left(\mathrm{g} / \mathrm{m}^{2} / 24 \mathrm{~h}\right)$ & -0.113 & 0.508 \\
\hline Mean triglycerides (mg/dL) & -0.055 & 0.607 \\
\hline Mean $\mathrm{Ca} \times \mathrm{P}\left(\mathrm{mg}^{2} / \mathrm{dL}^{2}\right)$ & 0.027 & 0.824 \\
\hline \multicolumn{3}{|l|}{ Rate of rGFR decline during the first year of CPD } \\
\hline Baseline rGFR $\left(\mathrm{mL} / 1.73 \mathrm{~m}^{2} / 24 \mathrm{~h}\right)$ & -0.607 & $<0.001$ \\
\hline Baseline proteinuria (mg/kg/24 h) & -0.225 & 0.046 \\
\hline Mean $\mathrm{Ca} \times \mathrm{P}\left(\mathrm{mg}^{2} / \mathrm{dL}^{2}\right)$ & -0.181 & 0.116 \\
\hline Mean SBP Z-score & -0.155 & 0.126 \\
\hline Mean alfacalcidol dose (ug/kg/week) & 0.104 & 0.351 \\
\hline 12-month increase in PD fluid volume $\left(\mathrm{mL} / \mathrm{m}^{2} / 24 \mathrm{~h}\right)$ & -0.124 & 0.434 \\
\hline $\mathrm{D} / \mathrm{P}_{\text {Crea } 4 \mathrm{~h}}$ & 0.081 & 0.446 \\
\hline 12-month increase in glucose load $\left(\mathrm{mg} / \mathrm{m}^{2} / 24 \mathrm{~h}\right)$ & -0.832 & 0.617 \\
\hline Mean triglycerides (mg/dL) & -0.006 & 0.952 \\
\hline \multicolumn{3}{|l|}{ Rate of daily diuresis decline during the second year of CPD } \\
\hline Mean alfacalcidol dose $(\mu \mathrm{g} / \mathrm{kg} /$ week $)$ & -0.271 & 0.307 \\
\hline $\mathrm{D} / \mathrm{D}_{0 \text { Glu } 4 \mathrm{~h}}$ & 0.287 & 0.374 \\
\hline 12 -month increase in PD fluid volume $\left(\mathrm{mL} / \mathrm{m}^{2} / 24 \mathrm{~h}\right)$ & 0.224 & 0.519 \\
\hline 12 -month increase in glucose load $\left(\mathrm{mg} / \mathrm{m}^{2} / 24 \mathrm{~h}\right)$ & 0.185 & 0.535 \\
\hline Mean total protein $(\mathrm{g} / \mathrm{dL})$ & 0.152 & 0.546 \\
\hline Proteinuria at 12 months $(\mathrm{mg} / \mathrm{kg} / 24 \mathrm{~h})$ & -0.128 & 0.558 \\
\hline Duration of CKD (years) & -0.097 & 0.746 \\
\hline \multicolumn{3}{|l|}{ Rate of rGFR decline during the second year of CPD } \\
\hline rGFR at 12 months (mL/1.73 $\left.\mathrm{m}^{2} / 24 \mathrm{~h}\right)$ & -0.499 & 0.044 \\
\hline Mean hemoglobin $(\mathrm{g} / \mathrm{dL})$ & 0.323 & 0.259 \\
\hline $\mathrm{D} / \mathrm{D}_{0 \mathrm{Glu} 4 \mathrm{~h}}$ & 0.281 & 0.354 \\
\hline Number of antihypertensive medications $(n)$ & -0.193 & 0.514 \\
\hline Proteinuria at 12 months (mg/kg/24 h) & -0.128 & 0.558 \\
\hline Mean total protein $(\mathrm{g} / \mathrm{dL})$ & 0.122 & 0.810 \\
\hline Mean $\mathrm{Ca} \times \mathrm{P}\left(\mathrm{mg}^{2} / \mathrm{dL}^{2}\right)$ & -0.022 & 0.933 \\
\hline Mean albumin $(\mathrm{g} / \mathrm{dL})$ & -0.026 & 0.957 \\
\hline
\end{tabular}

$\mathrm{CPD}=$ chronic peritoneal dialysis; $\mathrm{BMI}=$ body mass index; $\mathrm{PD}=$ peritoneal dialysis; $\mathrm{rGFR}=$ residual glomerular filtration rate; $\mathrm{Ca} \times \mathrm{P}=$ calciumphosphorus product; $\mathrm{SBP}=$ systolic blood pressure; $\mathrm{D} / \mathrm{P}_{\text {Crea } 4 \mathrm{~h}}=$ dialysate-to-plasma ratio for creatinine after 4 hours; $\mathrm{D} / \mathrm{D}_{0 \mathrm{Glu} 4 \mathrm{~h}}=$ dialysate-todialysate at 0 minutes ratio after 4 hours, $C K D=$ chronic kidney disease.

In our study group, we found in univariate analysis a negative effect of high calcium-phosphorus product on the rate of daily diuresis loss in the first year of PD, without significance of other parameters of calcium-phosphorus metabolism. Studies in adult patients showed a positive, negative, or neutral effect of calcium on preservation of diuresis $(12,29)$. Although hyperphosphatemia increases progression of predialysis chronic kidney disease (30), such a relationship was not confirmed in dialyzed patients. Our findings are partially consistent with the result of the multicenter NECOSAD study in adult patients treated with PD that showed no relation between the rate of diuresis decline and serum calcium, phosphorus, and PTH levels (29).

Limitations of the present study include its retrospective nature and a small number of patients in the second year of follow-up, which might have affected our findings, in particular failure to show continuing significant relations in the second year that were seen in the first year of chronic PD treatment. 


\section{CONCLUSION}

The most important risk factors for rapid RRF decline in children during the first year of chronic PD include higher baseline daily diuresis and proteinuria, and additional factors are systolic BP, PD fluid volume, and age at the onset of PD; while high baseline GFR and low peritoneal transport status may be the only important factors during the second year.

\section{DISCLOSURES}

The authors have no financial conflicts of interest to declare.

\section{REFERENCES}

1. Bargman J, Thorpe K, Churchill D. Relative contribution of residual renal function and peritoneal clearance to adequacy of dialysis: a reanalysis of the CANUSA study. J Am Soc Nephrol 2001; 12:2158-62.

2. Roszkowska-Blaim M, Skrzypczyk P. Residual renal function in children treated with chronic peritoneal dialysis. Scientific World J 2013; 154537 doi: $10.1155 / 2013 / 154537$.

3. Liao CT, Chen YM, Shiao CC, Hu FC, Huang JW, Kao TW, et al. Rate of decline of residual renal function is associated with all-cause mortality and technique failure in patients on long-term peritoneal dialysis. Nephrol Dial Transplant 2009; 24:2909-14.

4. Szeto CC, Kwan BC, Chow KM, Chung S, Yu V, Cheng ME, et al. Predictors of residual renal function decline in patients undergoing continuous ambulatory peritoneal dialysis. Perit Dial Int 2015; 35(2):180-8.

5. K/DOQI Clinical practice guidelines and clinical practice recommendations for 2006 updates: hemodialysis adequacy, peritoneal dialysis adequacy and vascular access. Am J Kidney Dis 2006; 48(Suppl 1):1-322.

6. Fischbach M, Terzic J, Menouer S, Soulami K, Dangelser C, Helmstetter A, et al. Effects of automated peritoneal dialysis on residual daily urinary volume in children. Adv Perit Dial 2001; 17:269-73.

7. www.espn-reg.org

8. Palczewska I., Niedźwiecka Z. Somatic development indices in children and youth of Warsaw. Dev Period Med 2002; 2(Suppl 1):1-120.

9. Warady BA, Alexander SR, Hossli S, Vonesh E, Geary D, Watkins S, et al. Peritoneal membrane transport function in children receiving long-term dialysis. J Am Soc Nephrol 1996; 7:2385-91.

10. National High Blood Pressure Education Program Working Group on High Blood Pressure in Children and Adolescents. The Fourth Report on the Diagnosis, Evaluation, and Treatment of High Blood Pressure in Children and Adolescents. Pediatrics 2004; 114:555-76.

11. K/DOQI Clinical practice guidelines for bone metabolism and disease in children with chronic kidney disease. Am J Kidney Dis 2005; 46(4 Suppl 1):1-122.

12. Liao CT, Shiao CC, Huang JW, Hung KY, Chuang HF, Chen YM, et al. Predictors of faster decline of residual renal function in Taiwanese peritoneal dialysis patients. Perit Dial Int 2008; 28:191-5.

13. Shin SK, Noh H, Kang SW, Seo BJ, Lee IH, Song HY, et al. Risk factors influencing the decline of residual renal function in continuous ambulatory peritoneal dialysis patients. Perit Dial Int 1999; 19:138-42.

14. Roszkowska-Blaim M, Skrzypczyk P, Jander A, Tkaczyk M, BałaszChmielewska I, Zurowska A, et al. The effect of peritoneal dialysis method on residual renal function in children. Adv Perit Dial 2012; 28:112-9.

15. Ardissino G, Tesla S, Dacco V, Vigano S, Taioli E, Claris-Appiani A, et al. Proteinuria as a predictor of disease progression in children with hypodysplastic nephropathy. Data from the Ital Kid Project. Pediatr Nephrol 2004; 19:172-7.

16. Singhal MK, Bhaskaran S, Vidgen E, Bargman JM, Vas SI, Oreopoulos DG. Rate of decline of residual renal function in patients on continuous peritoneal dialysis and factors affecting it. Perit Dial Int 2000; 20:429-38.

17. Kang SH, Cho KH, Park JW, Yoon KW, Do JY. Proteinuria as a risk factor for decline in residual renal function in non-diabetic peritoneal dialysis patients. Kidney Blood Press Res 2013; 37:199-210.

18. Konings CJ, Kooman JP, Gladziwa U, van der Sande FM, Leunissen KM. A decline in residual glomerular filtration during the use of icodextrin may be due to underhydration. Kidney Int 2005; 67:1190-1.

19. Bakkaloglu SA, Saygili A, Sever L, Noyan A, Akman S, Ekim M, et al. Assessment of cardiovascular risk in paediatric peritoneal dialysis patients: a Turkish Pediatric Peritoneal Dialysis Study Group (TUPEPD) report. Nephrol Dial Transplant 2009; 24:3525-32.

20. Oh KH, Moon JY, Oh J, Kim SG, Hwang YH, Kim S, et al. Baseline peritoneal solute transport rate is not associated with markers of systemic inflammation or comorbidity in incident Korean peritoneal dialysis patients. Nephrol Dial Transplant 2008; 23:2356-64.

21. Johnson DW, Mudge DW, Sturtevant JM, Hawley CM, Campbell SB, Isbel $N M$, et al. Predictors of decline of residual renal function in new peritoneal dialysis patients. Perit Dial Int 2003; 23:276-83.

22. Schaefer F, Klaus G, Mueller-Wiefel DE, Mehls 0 . Intermittent versus continuous intraperitoneal glycopeptide/ceftazidime treatment in children with peritoneal dialysis-associated peritonitis. The Mid-European Pediatric Peritoneal Dialysis Study Group (MEPPS). J Am Soc Nephrol 1999; 10:136-45.

23. Hidaka $H$, Nakao T. Preservation of residual renal function and factors affecting its decline in patients on peritoneal dialysis. Nephrology 2003; 8:184-91.

24. Lui SL, Cheng SW, Ng F, Ng SY, Wan KM, Yip T, et al. Cefazolin plus netilmicin versus cefazolin plus ceftazidime for treating CAPD peritonitis: effect on residual renal function. Kidney Int 2005; 68:2375-80.

25. van Olden RW, Guchelaar HJ, Struijk DG, Krediet RT, Arisz L. Acute effects of high-dose furosemide on residual renal function in CAPD patients. Perit Dial Int 2003; 23:339-47.

26. Li PK, Chow KM, Wong TY, Leung CB, Szeto CC. Effects of an angiotensinconverting enzyme inhibitor on residual renal function in patients receiving peritoneal dialysis. A randomized, controlled study. Ann Intern Med 2003; 139:105-12.

27. Suzuki H, Kanno Y, Suguhara S, Okada H, Nakamoto H. Effects of an angiotensin II receptor blocker, valsartan, on residual renal function in patients on CAPD. Am J Kidney Dis. 2004; 43:1056-64.

28. Kolesnyk I, Noordzij M, Dekker FW, Boeschoten EW, Krediet RT. Treatment with angiotensin II inhibitors and residual renal function in peritoneal dialysis patients. Perit Dial Int 2011; 31:53-9.

29. Noordzij M, Voormolen NM, Boeschoten EW, Dekker FW, Bos WJ, Krediet RT, et al. Disordered mineral metabolism is not a risk factor for loss of residual renal function in dialysis patients. Nephrol Dial Transplant 2009; 24:1580-7.

30. Voormolen N, Noordzij M, Grootendorst DC, Beetz I, Sijpkens YW, van Manen JG, et al. High plasma phosphate as a risk factor for decline in renal function and mortality in pre-dialysis patients. Nephrol Dial Transplant 2007; 22:2909-16.

This single copy is for your personal, non-commercial use only.

For permission to reprint multiple copies or to order presentation-ready

copies for distribution, contact Multimed Inc. at marketing@multi-med.com 